\title{
ملا هح دلالية في أسرار التقديم والتأخير في كتب إعراب القرآن الكريم
}

Semantic Features in the Advancement and Delay Mysteries in the Parsing Books of Al-Qur'an Al-Kareem

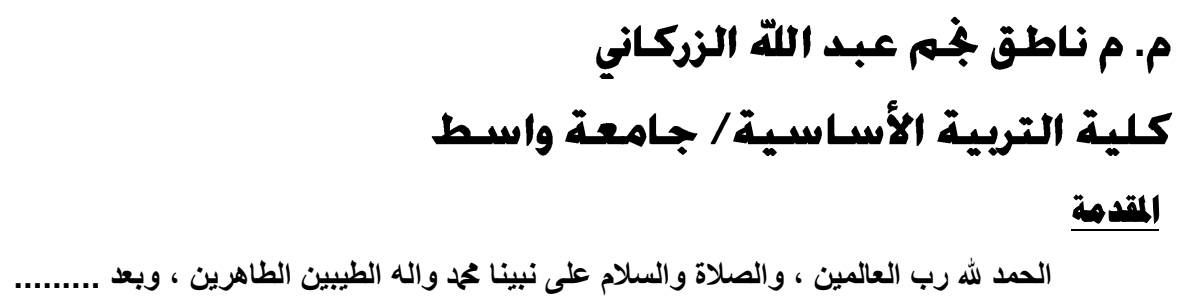

على الرغم من ان كتب اعراب القران الكريم كاتت معنية بايراد الوجوه الاعرابية للنص القراني ، وحجج هذه الوجوه الا ان هذه الكتب - مع ذلك ـ تضمنت ملامح دلالية تكثف عن اسرار التعبير في النص القراني ، وهذه الملامح الدلالية تارة مستفادة من اللفظة ، وتارة

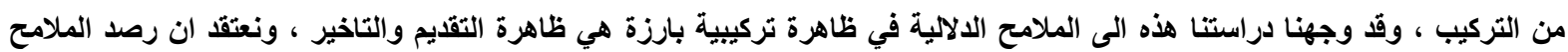
الدلالية لهذه الظاهرة في كتب اعراب القران يعد مسالة مهمة لاننا بذلك يتسنى لنا الوقوف عند الجهود المبكرة لعلماء العربية ـ معربي القران ـ في رصد المباحث الدلالية واثر هذه الجهود في كتب التفسير والبلاغة وعلماء التعبير القراني .اشتمل هذا البحث على مبحثين: الاول تناول الملامح الدلالية في التقايم والتاخير اللفظي، والمبحث الثاني تناول الملامح الدلالية في التقديم والتاخير الرتبي، وقد حاولنا في هذين المبحثين ان نقف اولا عند الاطار العام لهذه الظاهرة في كتب المعربين ، ثم بعد ذلك نورد جهودهم في رصد الملامح الدلالية. الكلمات المفتاحية :التقديم والتاخيز ـ اعراب القران الكريم ـ ملامع دلالية

Abstract

Although the parsing books of Al-Qur'an Al-Kareem are concerned with the representation of parsing aspects of Qur'anic text and these aspects' argumentations, these books which contain semantic lineaments are disclosed the mysteries of expressiveness at the Qur'anic text. These semantic features are sometimes advantaged from the pronunciational expression and sometimes they are benefited from the structure expression too. This study is devoted to the semantic features in a prominent structural phenomenon that is named the advancement and delay. The researcher thinks that the monitoring of semantic features, of this phenomenon at the parsing Al-Qur'an books, is regarded an important issue since it makes us observing the early works of Arabs' scholars - those who are parsing Al-Qur'an - at the observing of semantic sections and their efforts at the interpretation, rhetoric, and Qur'anic expressiveness books. This research is contained two sections: the first one is dealt with the semantic features at the pronunciational advancement and delay, whilst the second section is concerned with the semantic features at the ranked order of advancement and dela. At these two sections, the researcher is firstly tried to stand at the general framework of this semantic phenomenon at the scholars' parsing books, then he is mentioned their works at the monitoring of semantic features .

Key words: Features, semantics, mysteries, advancement, delay, parsing, pronunciational, rank.

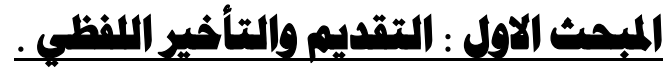

ونقصد به التقديم الذي يكون بين الالفاظ ، اذ ان من الظواهر الاعجازية للنص القراني هي ظاهرة اختيار المفردة ووضعها في المكان الملائم لها ، فكل لفظة من الفاظ القران الكريم وضعت في مكانها المقصود لتؤدي دوورها الدلالي المقصود ، فحينما تتقدم لفظة على اخرى فلا شك ان القران الكريم قصد هذا التقديم قصدا وان هناك علة تعبيرية محددة مقصودة ومن هذه الموارد التي رصدها المعربون في قوله تعالى : " \}إنَُّّْ 


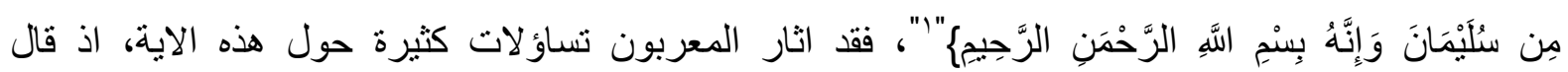

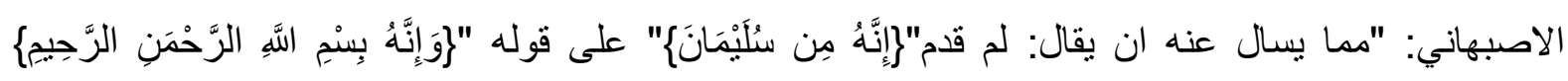

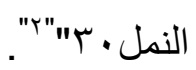

ولم يقف دور المعربين عند طرح التساؤلات بل تعدّوا ذللك الى ايجاد تعليلات تعبيرية من خلال الاجابة

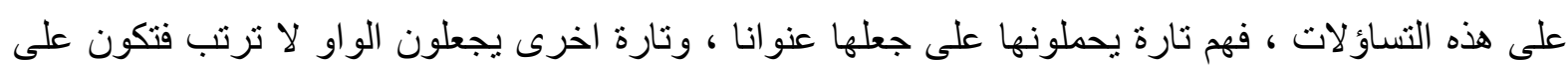
التقديم والتاخير ، وتارة اخرى يجعلون نعليلهم ان الكتاب لكافرة فخثي سليمان ان يكون منهم مكروه في اسم الله تعالى فقدم اسمه قبله"؟" ومن الملاحظ هنا ان الاصبهاني قد ادخل عنصر غير لغوي لينفذ من خلاله الى هذا الملمح الدلالي، فقد احتكم الاصبهاني الى السياق المقامي في تعليله هذا التقديم والتاخير مفترضا ان النبي سليمان " عليه السلام " و اقف على طبيعة ثقافة القوم ، وحالاتهم النفسية وانساقهم الثقافية في تعاملهم مع الاخر .اننا نلحظ أن الوقوف عند الملمح الدلالي لهذا الظاهرة يمثل اداة اجر ائية في حل اشكالية تفسيرية ، ومن ذلك ما

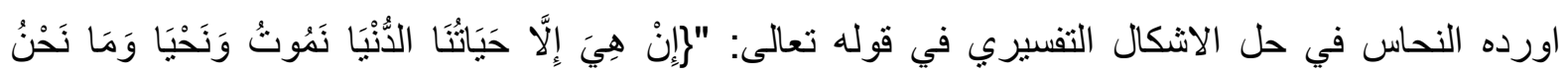

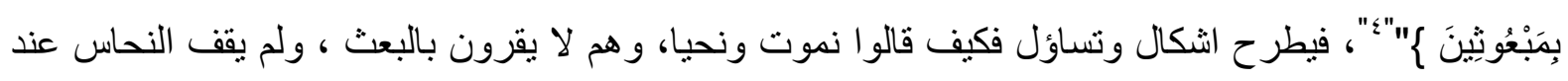
ذلك بل حلَّ هذا الاشكال من خلال تعليل ذلك تعليلا تعبيريا ، وطرح لذلك اكثر من وجه كان احدها ان حمله على التقديم والتاخير او انها بمعنى نموت ويحيا اولادنا ، ووجه اخر يكون المعنى من خلاله نكون اموات اي نطفا ثم نحيا في الدنيا "ه"

ومن التقديم والتاخير في الالفاظ التي وقف عندها معربو القران الكريم محللين ومعللين ،؛وكثفوا ملمحها الدلالي كما جاء في تقديم لفظ الجلالة " الله " على " الرحمن الرحيم "، وكذلك تقديم " الرحمن " على "

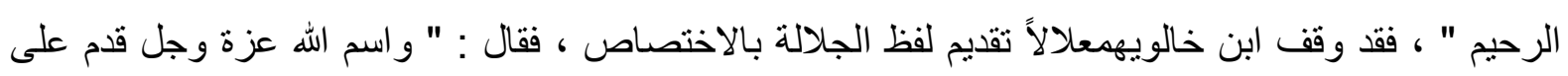

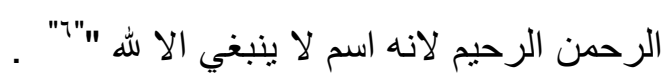

و الذي اتلمسه من تعليل خالويه فهو يعدُ ان لفظ الجلاله اسم جامعاً لكل الصفات التي تتفرع على العلمية التي تحمل جميع صفات الكمال الالهية المتفر عة الى الجمال و الكمال ، و أما الاسماء الاخرى فهي نثير الى جانب دن جلال الله تعالى ، ويستند قولنا هذا الى استقراء للقران لنعلم دون ادنى شكل ان هذا الاسم كان معروف حتى عند الكفار.

اما تقديم الرحمن على الرحيم فقد وفق المعربون عند ذلك وقفه طويلة محللين ومعللين، فقال أبن خالويه : " وقدم الرحمن على الرحيم لان الرحمة اسم خاص لله ، و الرحيم اسم مشترك يقال رجل رحيم و لا

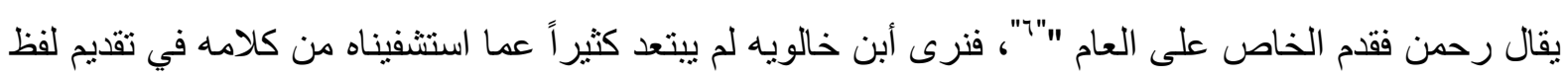
الجلاله"الله" على الرحمن الرحيم ، فكذلك نراه يعلل تقديم الرحمن على الرحيم كونه مختص بالله دون غيره ، فهو من باب تقديم الخاص على العام . 
فعلة التقديم عند ابن خالويهمبتنية على درجات الترتيب الكمالي لهذا الصفات الجمالية او الاسماء الجمالية ، فالرحمن اعلى رتبة من الرحيم اذ انهاسم مختص به تعالى لذا صح التقديم به او وجب التقديم به ، كذلك يمكننا ان ننظر الى هذا التقديم من زاوية اخرى مبتنية على الدلالة ، اذ أن اسم الرحمن يدل على سعة لئل

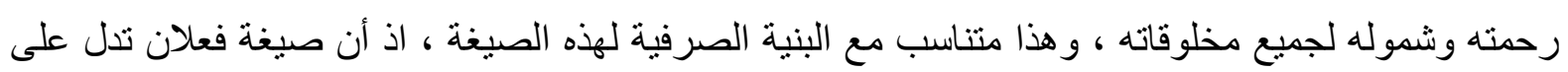
الكثرة و المبالغة "V" ، بينما الرحيم فصفة خاصة ، وهذا اما كدته الروايات الوارده عن أهل البيت عليهم السلام اذ ورد عن الامام الصادق عليه السلام قوله "الرحمن بجميع خلقة ، الرحيم بالمؤمنين خاصة فورد عنه ايضاً

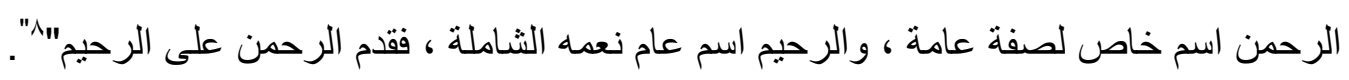

ومعربو القران الكريم كثير ا ما يحكمون المقام والسياق في تعليلهم في تقديم هذه اللفظة على تللك ،

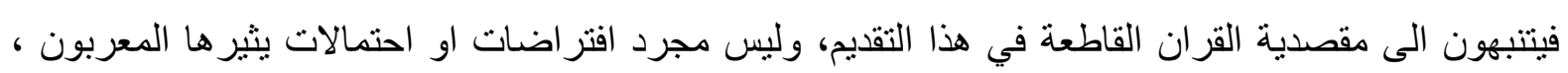

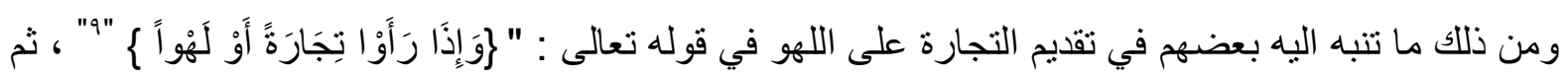

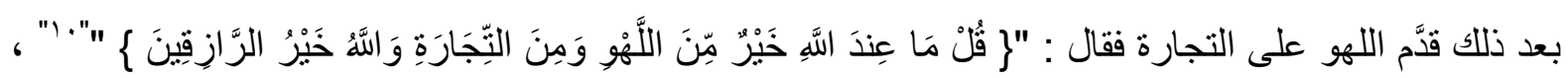
فقد علل المجاشعي في كتابه النكت في اعراب القران ، و الاصبهاني في كتابه اعراب القران ذلك بان التجارة هي المطلوبة ، و الفائدة فيها، و اللهو لا فائدة فيه ، فاعلمهم انهم اذا راوا تجارة انفضوا اليها ، وعجزَّهم بذلك فئك وبكَّتهم ؛ لانهم يعذرون في بعض الاحوال على التجارة، ولا يعذرون على اللهو؛ لانه ليس مما برغب فيه العقلاء كما بر غبون بالتجارة .

امَّا سبب تاخير التجارة وتقديم اللهو في الاية المباركة الثانية ؛ فلانه ار اد ان يعلمهم ان ما عند الله خيرا مما لافائدة فيه ، ومن الذي فيه فائدة "'ا" ، وهذا التعليل التعبيري هو ما يتبناه بعض المعربين المحدثين ،

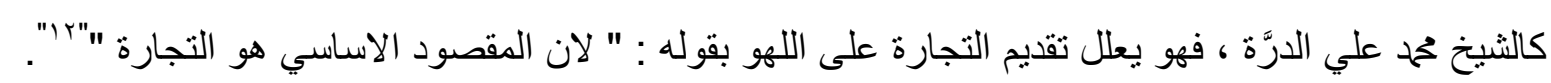
ثمَّ يعلل تقديم اللهو وتاخير التجارة بقوله : " لان الخسارة بما لا نفع فيه اعظم ""rا" ، و هنا نلاحظ ان المعربين قد افادوا من سنن العربية وقو اعدها في الكلام في تعليلهم التعبيري هذا ، فهم قد صرحوا بذلك حينما

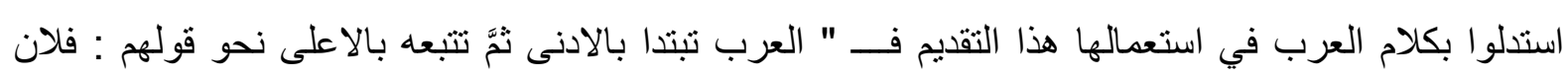
يعطي العشرات و المئين والالف ""؛ ا" ، فهذا يدلنا على ان فهم معاني القران واستجلاء مقاصده يتوقف في كثير من الاحايين على فهم كلام العرب وقو اعد العربية ومقاصدها .

ان التعليل الذي قَّمَه المعربون هو ما اعتمده اكثر المفسرين"ه" ، وهذا لا يدلُّ على ان هذا التعليل التعبيري هو الوجه الوحيد في تعليل تقديم التجارة على اللهو نارة وتاخيرها نارة اخرى ، فقد راى الدكتور فاضل السامر ائي انَّ سبب تقديم التجارة على اللهو ؛ لانها كانت سبب الانفضاض ذلك الك انه قدمت عير المدينة ، وكان النبي "صلى الله عليه واله وسلم " يخطب يوم الجمعة ، وكان من عرفهم ان يدخل بالطبل والدفوف

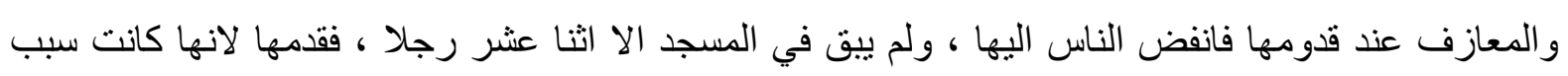
الانفضاض ، وانما كان اللهو والضرب بالدفوف بسببها ، ولهذا افرد الضمير في قوله " اليها " ، ولم يقل : "اليهما " ؛ لانه في الحقيقة انما انفضوا الى التجارة ، وكان قد مسَّهم شيء من غلاء الاسعار ، و امَّا سبب تقديم اللهو عليها لان اللهو اعم من التجارة فليس كل الناس يشتغلون في التجارة ، ولكن اكثرهم يلهون ، فالققراء 
و الاغنياء يلهون ، فكان اللهو اعمَّ فقدَّمهه ، ولذلك ، اذ كان حكما عامَّا ، فقَّمّ التجارة في الحكم الخاص لانها في

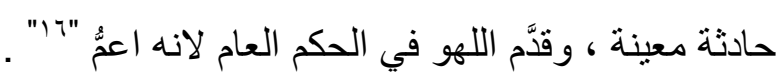
و الباحث لا يرى ان ما قدَّمه المعربون يتقاطع مع التعليل التعبيري الذي قدَّمه الدكتور فاضل السامر ائي

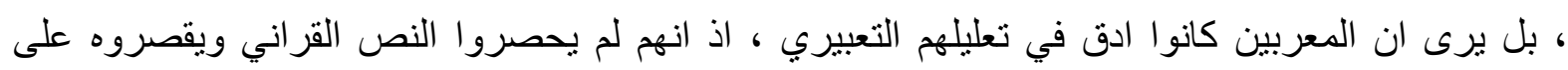
تاريخ النزول وسببه ، بل اعطوا للنص اطلاقه و عمومه ليكون شاملا لكل زمان ، وهم بذللك قد جسدوا ما تبناه الاصوليون من ان العبرة بعموم اللفظ لا بخصوص السبب" بار" ، في حين اننا مع الدكتور فاضل صالح السامر ائي نستشعر اننا في هذا النص نعيش اجواء النزول ، وتاريخ الحادثة فيترك ذلك انطباعا على المتلقي بان الاية المباركة محددة بعصر نزولها ، وهذا لا بعني اننا نرفض ان يكون لسبب النزول مدخلية في فهم النص القراني ، بل انتا نعتقد ان سبب النزول له دور اساس في فهم القران الكريم ، ولكن من دون ان بحصر النص به ويقصر عليه . 20 - 20

ومن ذلك ما وقف عنده المعربون محللين ومعللين في تقديم بعض الالفاظ وتاخير ها تارة اخرى ما جاء

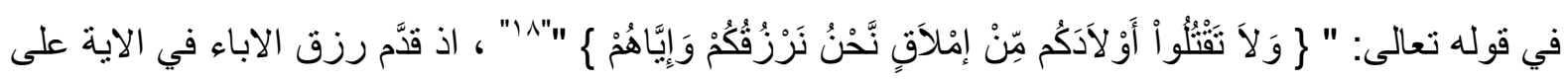

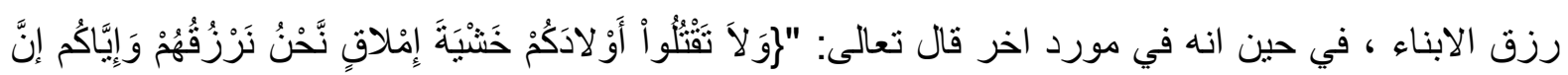

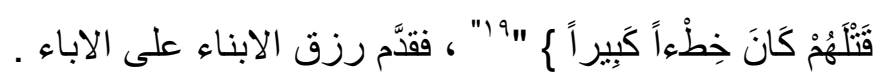
وقد علل معربو القران الكريم المحدثون تقديم و عد الله برزق الاباء على الابناء في ان سبب ذلك يعود الى ان الخطاب كان متوجها الى الاباء المملقين اذ اقتضت البلاغة ان يعدهم الله بان يغنيهم من الرزق ، ثم بعده

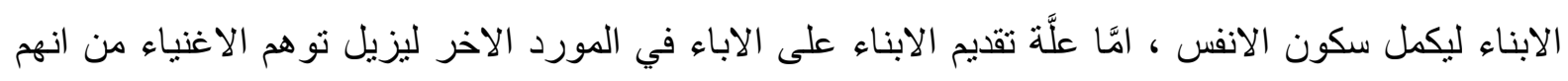
بانفاقهم على الابناء يصيرون الى تفريق الغنى ، ثم كمّل هذه الطمانينة بعدتهم بالرزق بعد عدة ابنائهم ، فليس

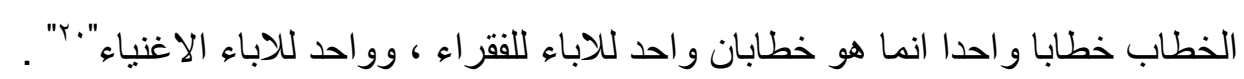

ومعربو القران الكريم في تعليلهم هذا تنبهوا الى ان القران الكريم قد راعى فنون البلاغة في مطابقة الكلام لمقتضى الحال ، الا انهم لم يقدموا لنا دليلا على تبنيهم هذا التعليل التعبيري مع ان القرائن السياقية

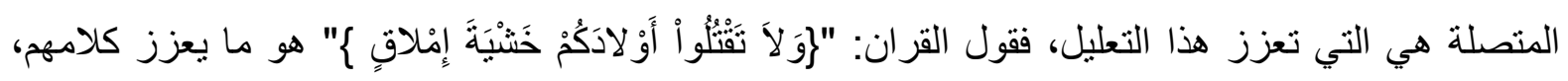
فالخثية تمثل الخوف المستقبلي للاباء، و هو ما يعكس لنا حالة الاباء وقت ذلك الخوف اذ ان ذلك يدلنا على انهم

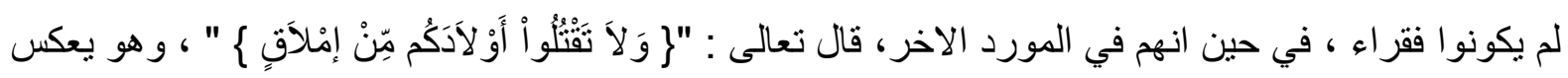
لنا ان الفقر هي حالة مصاحبة للاباء وقت الخطاب ؛ ولذلك نجد ان المجاشعي القيرواني والاصبهاني في اعر ابيهما قد تتبها الى ان القران الكريم يتحدث عن خطابين موجهين للاباء حينما عالجا الاشكال الذي مفاده انه

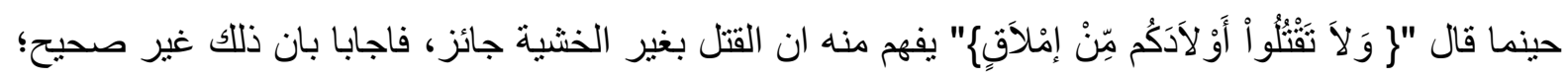
لان النص القراني في بيان مكان الخوف"اץ"، وهذا يدل على ان النص جاء ليحدد نوع الخطاب ويبين سببه بالخشية والخوف، في حين ان المورد الاول، والخطاب الاول لم يقيد بالخشية والخوف ، فل على انهما خطابان متغايران وليس هما خطابا واحدا، وكان لكل خطاب مقامه وسياقه ـ. ومن ضمن معالجات معربي

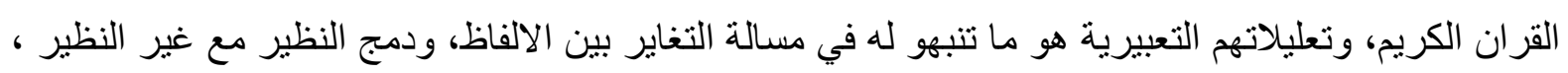




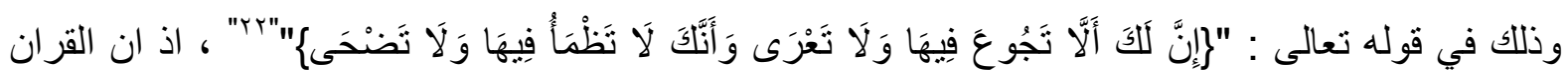

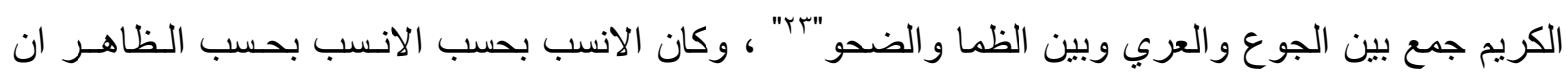

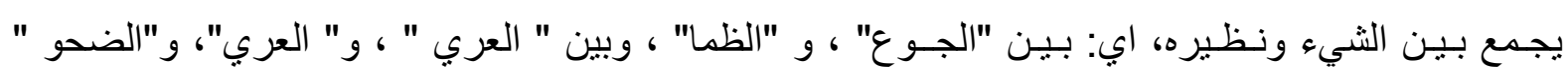

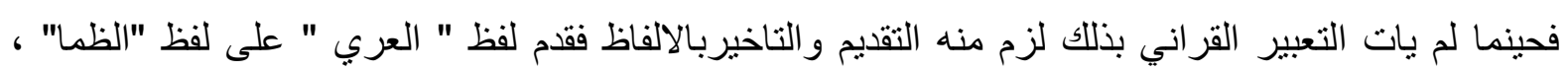
واخر لفظ "الظما" عن " العري" ، وفي ذلك قدَّم المعربون اجوبة تعليلية تعبيرية متعددة ومتنوعة في ذلك ، فمن ذلك ما قدماه المجاثعي والاصبهاني ، اذ انعما رايا ان علة هذا الجمع بين هذه الالفاظ جاء بسبب اجتماع هذه الالفاظ في المعنى ، فالجوع و العري ينشابهان ، اذ ان الجوع عري في الباطن من الغذاء ، و العري ظاهر

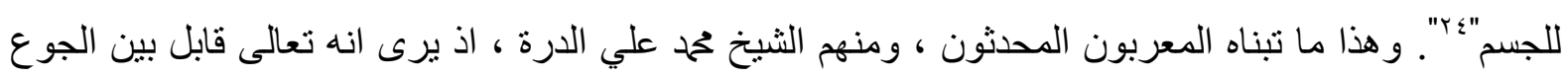
و العري لان الجوع ذلُّ الباطن و العري ذل الظاهر ، و الظما حرّ الباطن، و الضحو حرّ الظاهر ، فنفى عن ساكن

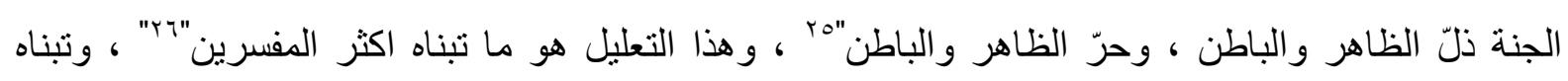

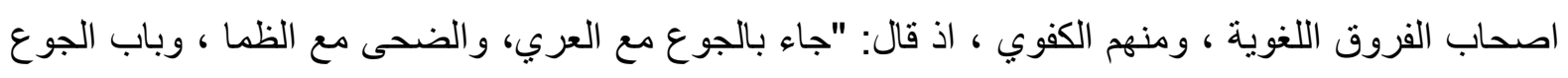

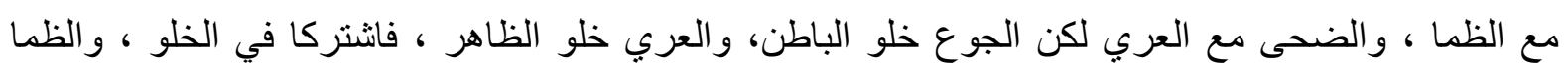

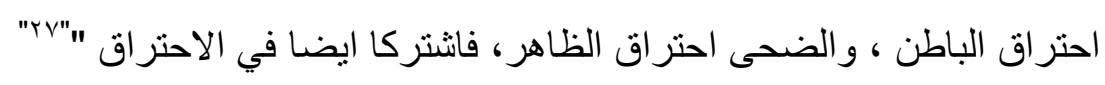

و هناك تعليل تعبيري اخر قدمه بعض المعربين المحدثين ايضا مفاده انه لو رتب القران الكريم هذه

الالفاظ بحسب ما تو همه المتو هم فان ذلك يستلزم فساد في النظم لانه لو قيل : ان للك ان لا تجوع فيها ولا تظما لوجب ان يقول و انك لا تعرى فيها ولا تضحى ، والتضحي البروز للثمس بغير سترة فيكون المعنى عندئذ التعري فيصير معنى الكلام وانك لا تعرى فيها ولا تعرى وهذا فساد ظاهر ولما كان هذا الفساد لازما للنظم على الوجه الذي توهمه المتو هم عمد القرآن الكريم عندئذ الى التقديم والتاخير في هذه الالفاظ ليصح النظم ونتجنب تكرار المعاني ، فضم الله سبحانه وتعالى لنفي الجوع نفي العري لنطمئن النفس بسد الجوع وستر العورة الذين تدعو اليهما ضرورة الحياة ، ولما كان الجوع مقدما على العطش كتقديم الاكل على الثراب

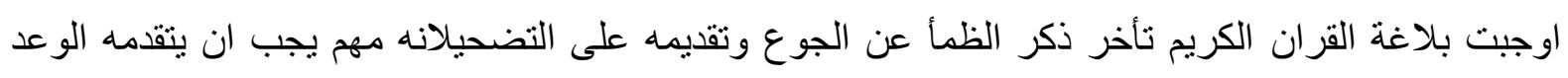
بنفيه ، كما تقدم الوعد بنفي الجوع ، ويتاخر ذكر التضحي كما تأخر ذكر العري عن الجوع ؛ لان التضحي من

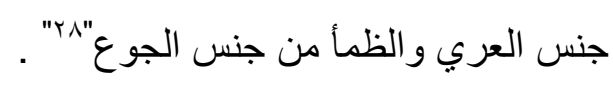

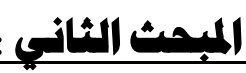

اما القسم الاخر الذي عالجه معربو القران الكريم ، فهو تقديم اللفظ على عامله وقد تتوعت معالجاتهم في هذا النوع من التقديم ، فهم تارة يكتفون برصد صور التقديم والتأخير في النص القراني من دون ان يشيروا

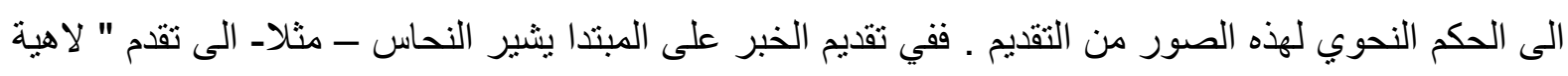

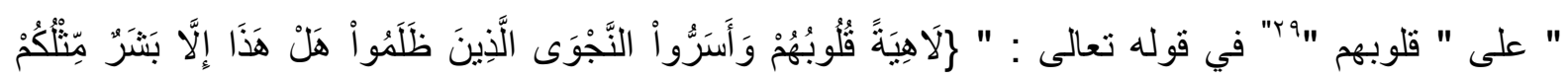

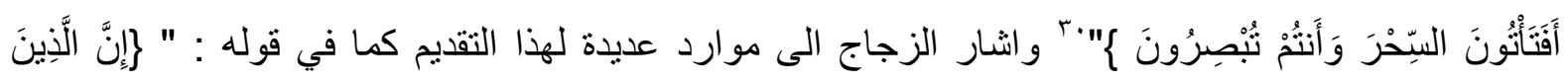

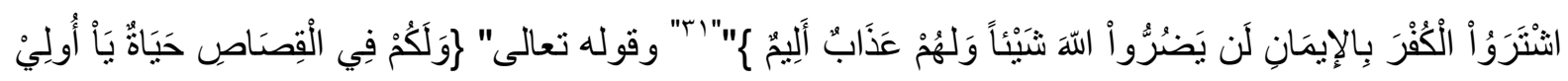

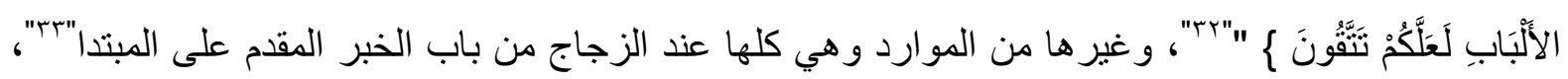


وهذا الرصد نجده عند العكبري والانباري وابن خالويه والهمداني والتبريزي فضلا عن معربي القران المحدثين. وتنو عت صور التقديم التي رصدها المعربون فنجدهم يشيرون الى تقدم المفعول على فعله ، وتقديم المنصوبات على عاملها، وتقديم الجار و المجرور على متعلقه ، وتوسعت صور التقديم عندهم الى رصدهم لصور التقديم في الجمل كالتقديم في المعطوفات و الثرط ، والقسم وتقديم جملة الصلة وغير ها من مظاهر

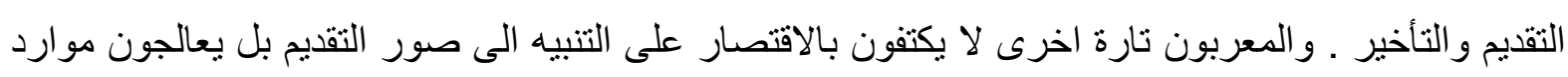

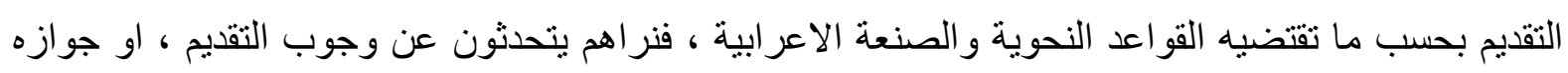
في مواضع وروده في النص القراني.

و المعربون في اكثر معالجاتهم لمو اضع ورود التقديم يصبون اهتمامهم على الثكل ، ويحكمون الصنعة النحوية والاعرابية ولهذا نجد ان علل التعبير لهذا التركيب القراني ضئيل في مصنفاتهم ، بل هم ييتعدون احيانا عن اسر ار هذا التركيب و علل التعبير فيه حينما يساوون في موارد متعددة بين التقديم وعدمه مثلما صنع ابن خالويه ، اذ يرى ان المعنى في التقديم والتاخير واحد في مثل قوله تعالى "رالْحَمْدُ للّهِ رَبِّ الْعَالَمِينَ

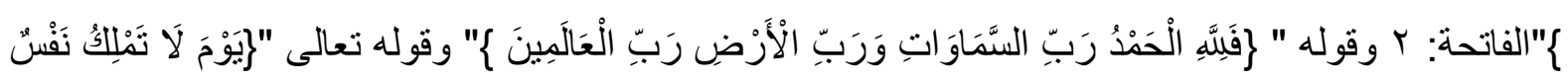

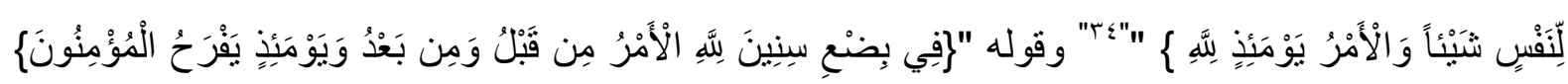

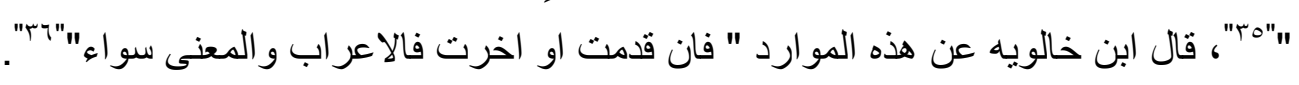

و الو اقع انه لو اجرى تحليلا دقيقا لسياق هذه الموارد لتبين ان كل مقام يتطلب تركيبا معينا يناسبه ، فقي سورة الجاثية حينما قال "له الحمد" نجد ان المقام اقتضى تقديم الذات الالهية المستحقة للحمد لما في التقديم من غرض الاختصاص ، اذ ذكرت في هذه السورة اصنافا من الكفار ، وفصلت في ذكر عقائدهم ومواقفهم من

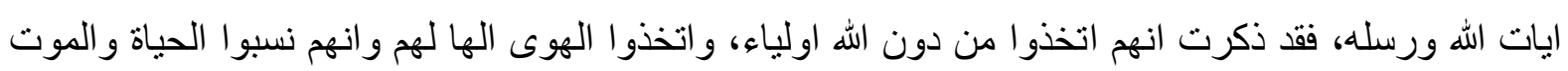
الى الدهر لا الى الله ، فلم يعترفوا لله بشيء من خصائص الربوبية والالو هية ، ولم يقروا بفضل له على الانسان

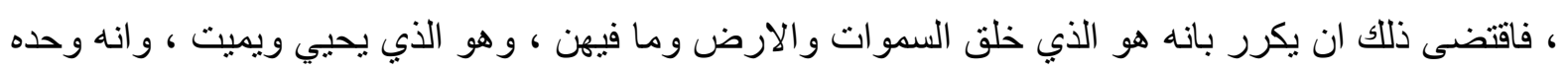
المتفضل في هذا الوجود لا متفضل سواه على الحقيقة، فهو الذي انزل المطر وسخر البحر وفعل وفعل ، فهو ولهو المستحق الحمد على جهة الحصر والقصر، فقدم الذات الالهية وقصر الحمد عليه ;لان المقام يقتضي ذلك

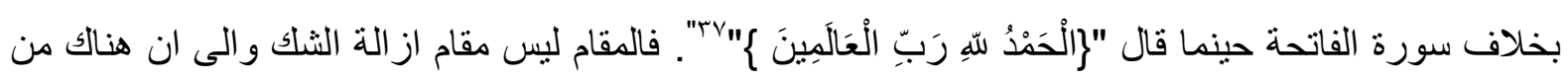

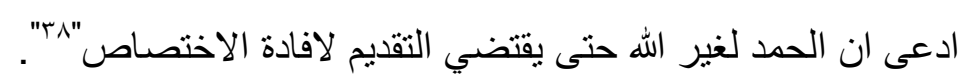

واهتمام معربي القران بالثكل والصنعة النحوية والاعرابية في معالجتهم هذا التركيب القراني قد

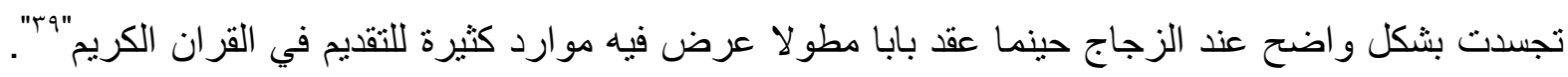
اذ ابتعد عن بيان اسر ار هذا التعبير ومكامن دقائقه والباحث هنا حينما يخلص الى الصنعة النحوية على انها هي المحور الذي تدور حوله معالجات معربي القران فانه لا ينفي ان يكون المعربون قد لفتوا الى تعليلات تعبيرية تكثف عن اسرار هذا التركيب القراني، و لا سيما عند المتأخرين والمحدثينو ونرى ان معربي القران القدماء حينما اعادوا ترتيب الجمل في النصوص القرانية على اساس المعنى يكونوا بذلك قد لفتوا الى اسرار هذا ونا 
التركيب بشكل غير مباشر ف"الالفاظ اذا كانت اوعية للمعاني فانها لا محالة تتبع المعاني في مواقعها ، فاذا وجب المعنى ان يكون اولا في النفس وجب اللفظ الدال عليه ان يكون منله اولا في النطق" ؛ـ".

فكما ان التقديم والتاخير يعدُّ قرينة على تحديد الوظائف النحوية ، فهو قرينة ايضا على تحديد المعنى،

فـ " اللفظ و المعنى هما المكون الاساسي لاي كلمة او تركيب ، و اللفظ يمثل جانب الثكل او الظاهر ، و المعنى يمثل جانب المحتوى او العمق. و عند رصد هذين الجانبين من زاوية النطق و الممارسة اللغوية نلحظ ان المعنى لاحق للفظ ، و الاصل المفترض في علاقتهما ان يكون هناك تطابق بينهما ، اي ان يكون احدهما مساوٍ لمقدار الاخر في خصائصه ودلالاته ""اء"، و هذا ما لفت اليه معربو القران ، فهم يعيدون ترتيب الجملة لفهم ذلك هلك

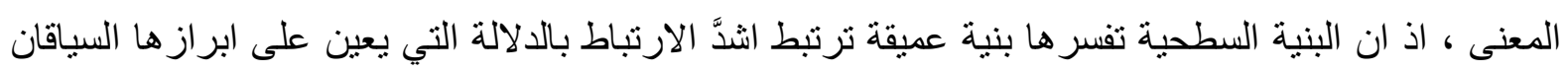

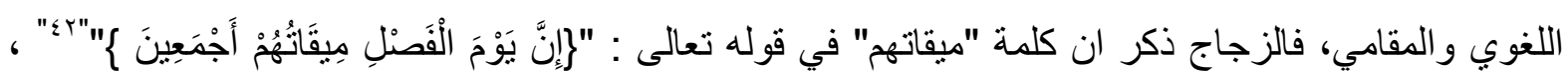
قرئت بالرفع و النصب، وقد فرَّق الزجاج بين المعنيين ، قال: "فمن قرا ميقاتهم بالرفع جعل الفصل اسم " ان "

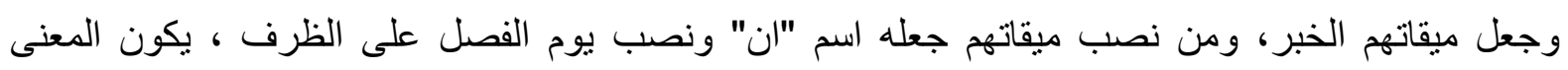

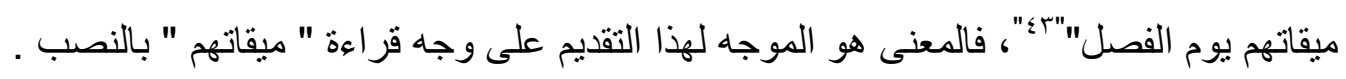

وفي تقديم المفعول به على الفعل نتلمس ادراكا واضحا عند المعربين لاسرار هذا التقديم ، اذ جاءت تعليلاتهم تعبيرية ، فقد ارتبط هذا التقديم عندهم بالغرض البلاغي ، اذ نقل النحاس قول سيبويه في الغرض من تقديم المفعول به، وهو " انهم يقدمون الذي بيانه اهم عليهم ، وهو ببيانه اعنى ، وان كانا جميعا يهمانهم

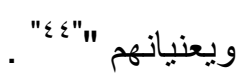

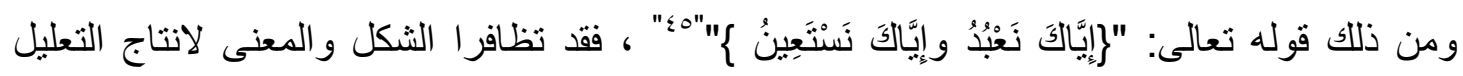
التعبيري ، فالمفعول به " اياك " مقدم وجوبا ، لانه ـ ـ كما ذكر الزجاج ومكي بن ابي طالب و ابن خالويه ـ لو لو تاخر لم ينفصل ، ولصار كافاً متصلة فقلت نعبدك" "ج؛ ، وهذا يمثل الجانب الثكلي في هذا التقديم ، وتقدير هؤلاء

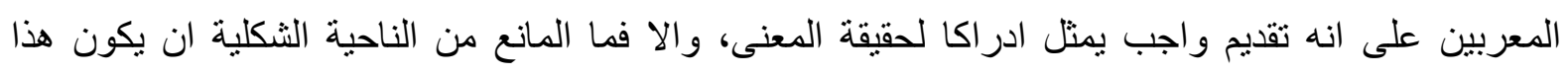
التقديم جائزا ما دامت القرائن النحوية غير مانعة منه، وهذا يتو اءم مع ما ذكره اكثر اللغويين و البلاغيين من ان ونان المفعول اذا قُدِّم فانه يفيد الاختصاص، فالسكاكي جعل التقديم احد طرق القصر ، ومنه تقديم المفعول به ، ومثل ونل

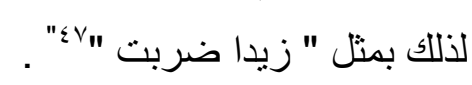

و هذا ما ذكره ابن الاثير حينما مثل بقوله : " زيدا ضربت " ، قال : "لانك اذا قدمت الفعل كنت بالخيار

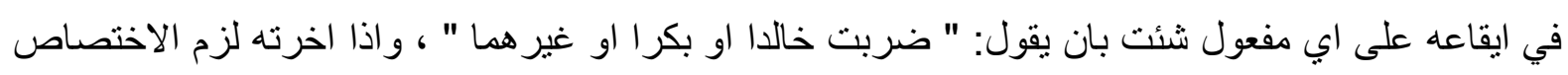
للمفعول""^ء". وبهذا الغرض البلاغي مضىى المفسرون و اللغويون على ان تقديم الضمير في اياك " الذي هو المفعول به " ، على فعل العبادة ، و على فعل الاستعانة هو لبيان ان العبادة و الاستعانة مختصان بالهه تعالى ، فلا يعبد احدُ غيره ، و لا يستعان به "وء". وبذلك قال المعربون المحدثون ، قال الدرويش : " قدم الضمير لحصر

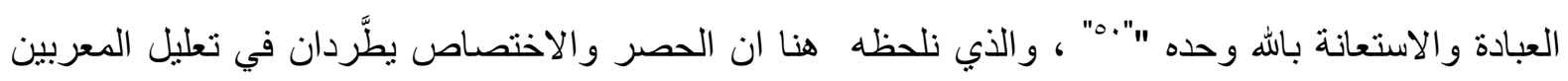
لهذا التقديم ، وهما مصطلحان مترادفان عندهم ، الا ان الدكتور هادي نهر في كتابه " الاتقان في النحو

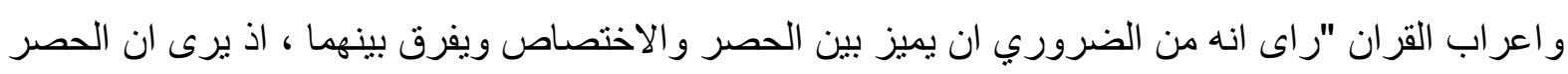


وجها واحدا من وجوه القصر ، فالحصر غير الاختصاص ؛ لان المراد بالحصر نفي غير المذكور ، واثبات المذكور ، امَّا الاختصاص فهو نفي الخاص من جهة خصوصية ؛ لان كل مركب من خاص و عام له جهتان ، فقد يقصد من جهة عمومه ، وقد يقصد من جهة خصوصه ، و الثاني هو الاختصاص ، و وانه هو الاهم عند

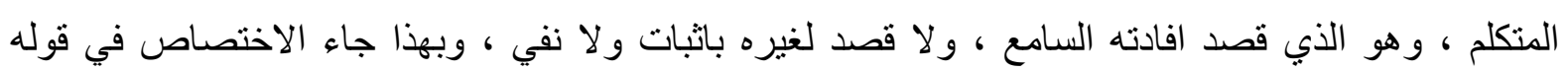

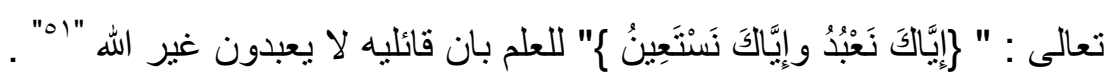
واستدل الدكتور هادي نهر على ان المعنى للاختصاص لا للحصر بقوله تعالى : "افغير دين الله ييغون

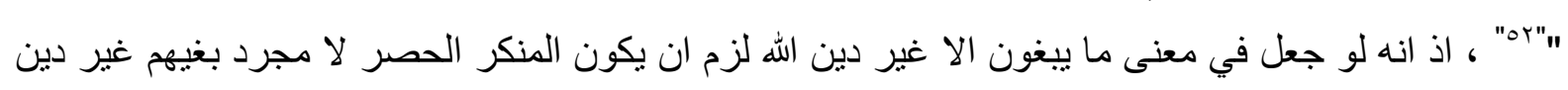

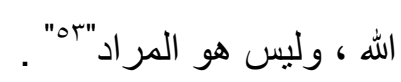

و هذا الفرق بين الحصر والاختصاص الذي قدمه الدكتور هادي نهر سبقه اليه السبكي"ه" ، ، ووفقا لهذا

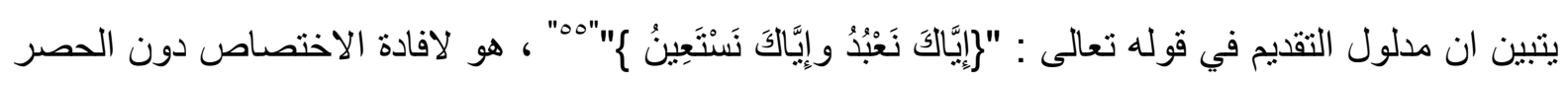
؛ لان المصلي يكون مقبلا على الله وحده لا يعرض له استحضار احدا غيره ، ولم يخطر بباله احد سوى الله

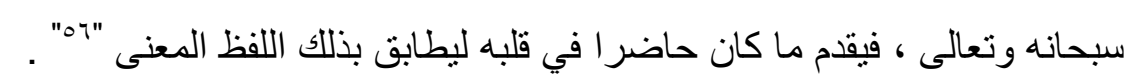
وتمضي اثشارات المعربين في عد غرض الاختصاص هو العلة التعبيرية لتقدم المفعول به في مواضع قرانية كثيرة ، كما في قوله تعالى : "يا ايها الذين امنوا كلوا من طيبات ما رزقناكم واشكروا لله ان كنتم اياه

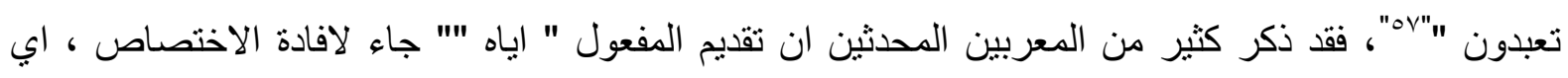
و اشكروا له لانكم تخصونه بالعبادة ، وتخصيصكم اياه بالعبادة يدل على انكم تريدون عبادة كاملة تليق بكبريائه

ووقف المعربون معللين ومحللين لتقدم المنصوبات الاخرى ، ومن ذلك ما وققوا عنده في تعليل تقدُّم " اربعين " على عامله " يتيهون " في قوله تعالى : ""هوه" فقد اشار الزجاج ومكي بن ابي طالب الى ان " اربعين

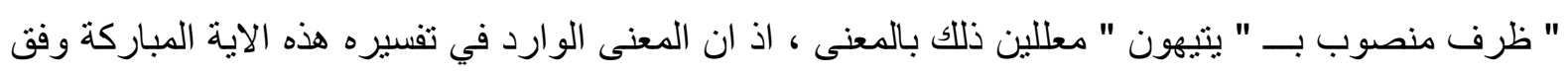
ماثور الروايات ، اذ ان الله تعالى منع بني اسر ائيل من دخول الارض المقدسة منعا تكوينيا تابيديا ، ولم يدخلها

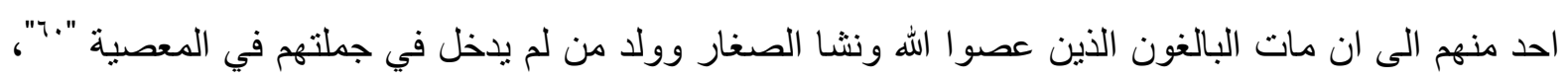
و هذا ما تبناه اكثر المفسرين "آ" ، و على الرغم من ان عددا من المفسرين واللغويين ومعربي القران الكريم

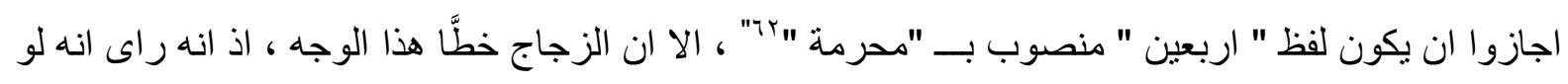
نصبت بلفظة " محرمة " كان المعنى انها محرمة عليهم اربعين سنة فقط ، و هذا مخالف لما عليه التفسير "بج". و هذا يؤكد لنا بشكل واضح ان المعنى قد بتحكم في الاعراب والتحليل النحوي عند معربي القران ، مما جعلهم يختارون عاملا دون اخر ، ويؤثرون التقديم معللين له بالمعنى ومن الموضوعية بمكان ان نذكر هنا ان معربي القران كثير ا ما يشيرون الى تقدم المنصوبات دون ان يعللوا لذلك التقديم ، كما في تقدم الحال اذ يكتفون

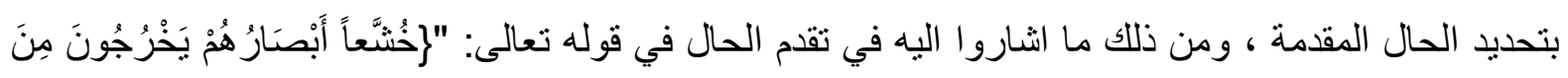

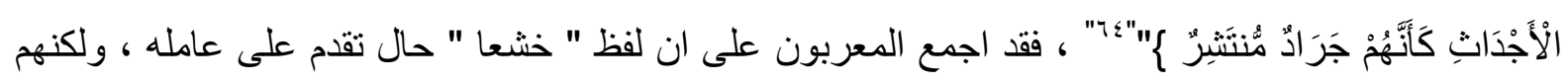

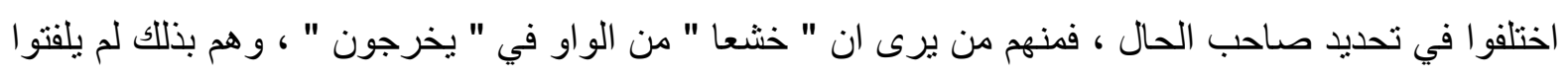


الى العلة التعبيرية في تقدم الحال على صاحبها ، اذ ان تقديم الحال على صاحبها يفيد غرضا بلاغيا براد به

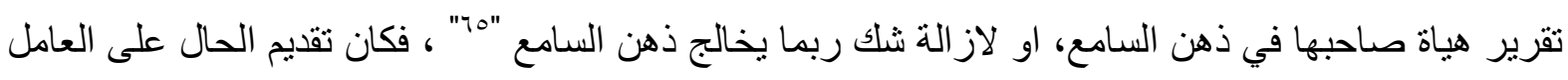
فيه في هذه الاية المباركة لبيان هياة الابصار وذلها وخشوعها ، ولو كان الحال متاخر العدمنا ذلك التصوير

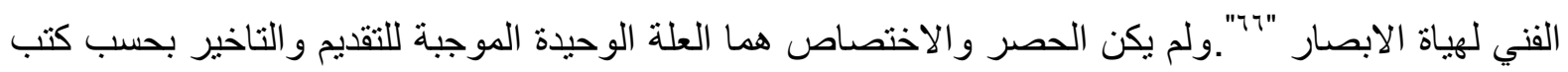
اعراب القران الكريم ، اذ اننا نجد ان الاغر اض البلاغية الاخرى كان لها حضورا في تعليل التقديم ، فالاهتمام

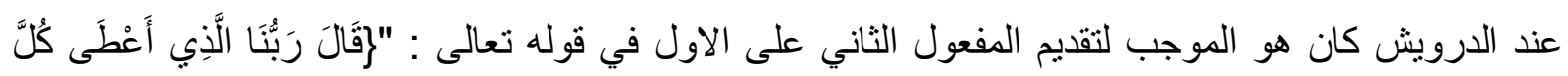

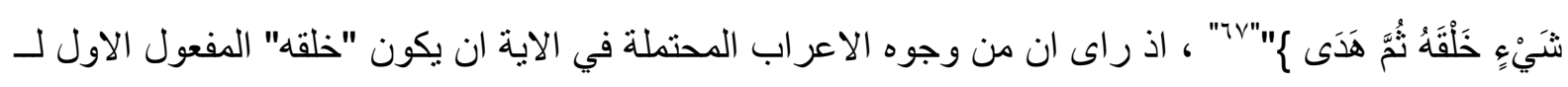

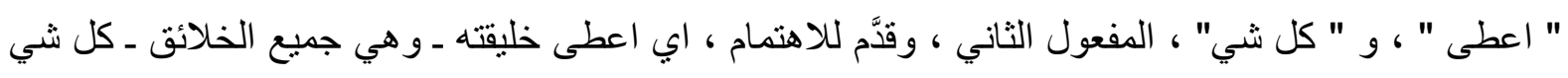
يحتاجون اليه"^ج" .و ادرك العكبري ما للتقديم من اثر في البناء الموسيقي للنص القراني ، اذ ان التقديم له دور في تشكيل البنية الايقاعية للنص القراني فهو " من الوسائل التي يلجا اليها الفنان ليوفر الايقاع في فنه ، وليكسب فيه روعة وجاذبية ، ويحرك النفوس له ، بوضع الكلمة في مكانها المناسب بحيث تلتحم الكلمة بالاخرى ،

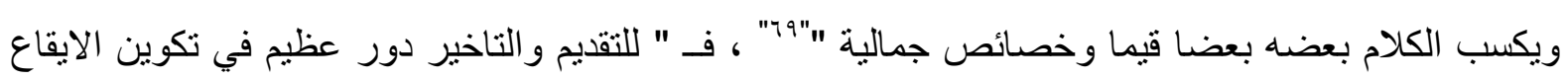
في النص القراني ، خاصة في تحقيق الانسجام بين الفواصل مما اعطى العبارة القرانية وقعا خاصـا ، و ايقاعا

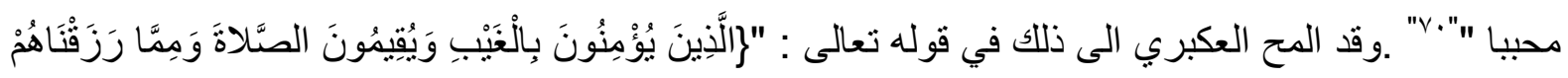

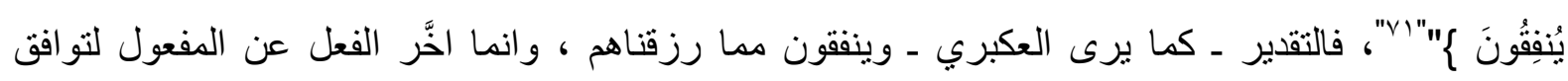

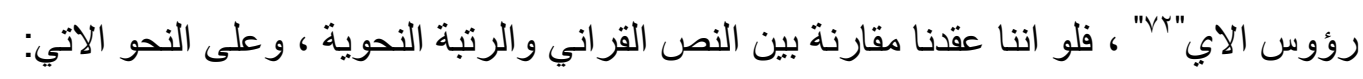

$$
\text { ومما رزقتاهم ينفقون } \quad \text { والنص الرنبة النحوية الاصلية } \quad \text { وينفقون مما رزقناهم }
$$

لتبين لنا الفرق في قوة الايقاع وبروزه في حقل التقديم والتاخير ، و عدم وضوحه في الرتبة الاصلية للتركيب النحوي.

ولمعربي القران الكريم اشار ات كثثرة بعللون فيها التقديم رعاية للفاصلة القرانية" رؤوس الاي بحسب تعبير هم " و هم بذلك تو افقو امع الكثير من اللغويين و البلاغيين و المفسرين في عدِّ التقديم و التاخير ركيزة اساسية

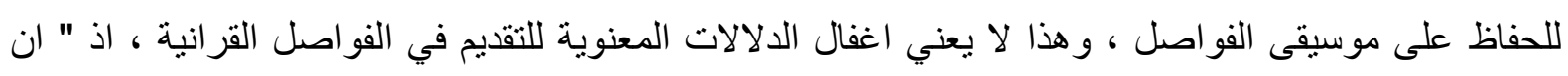

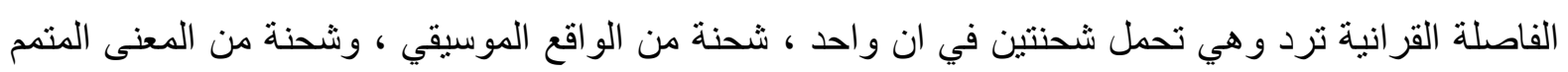
للاية""rर" ، فالدور الموسيقي الذي تضفيه الفاصلة على النص لا يكون على حساب المعنى ، بل ياتي تباعا له ،

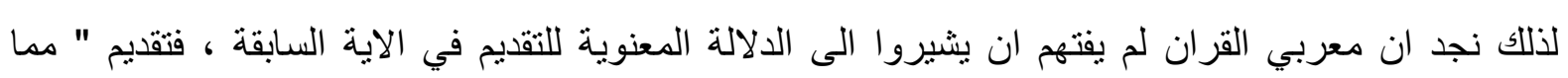

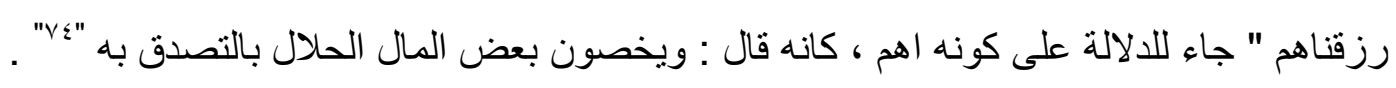

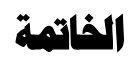

بعد هذا العرض التقصيلي لجهود معربي القرآن قديم وحديثا في الكثف عن أسرار التعبير القرأني و علله لظاهرة التقديم والتأخير في القرآن الكريم ظهر لنا جليا أن هذه الظاهرة شكلت انموذجا أسلوبيا للتدليل على الاعجاز القرآني فعلى الرغم من أن معربي القرآن الأوائل كان توجههم وغايتهم في تأليف كتب الاعراب 
هو بيان الوجوه الاعرابية للنص القرآني الا أنهم مع ذلك استوققته هذه الظاهرة مثل غيرها من الظواهر الاسلوبية في النص القرآني فألمحوا لها في اشارات عابرة أفاد منها بعد ذلك المفسرون ومعربو القرآن المتأخرين اذ وسعوا من دراستهم هذه الظاهرة فأستجلوا أسرارها وكثفوا أفانيين أساليبهم فتنوعت عت عندهم علل التقديم ووظائفه في النص القر آني ، ولم تعد ظاهرة التقديم بعد ذلك ظاهرة عابرة يتصف بها اي نص أدبي ،بل

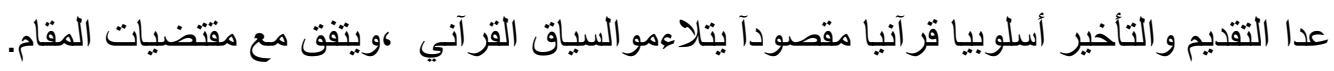

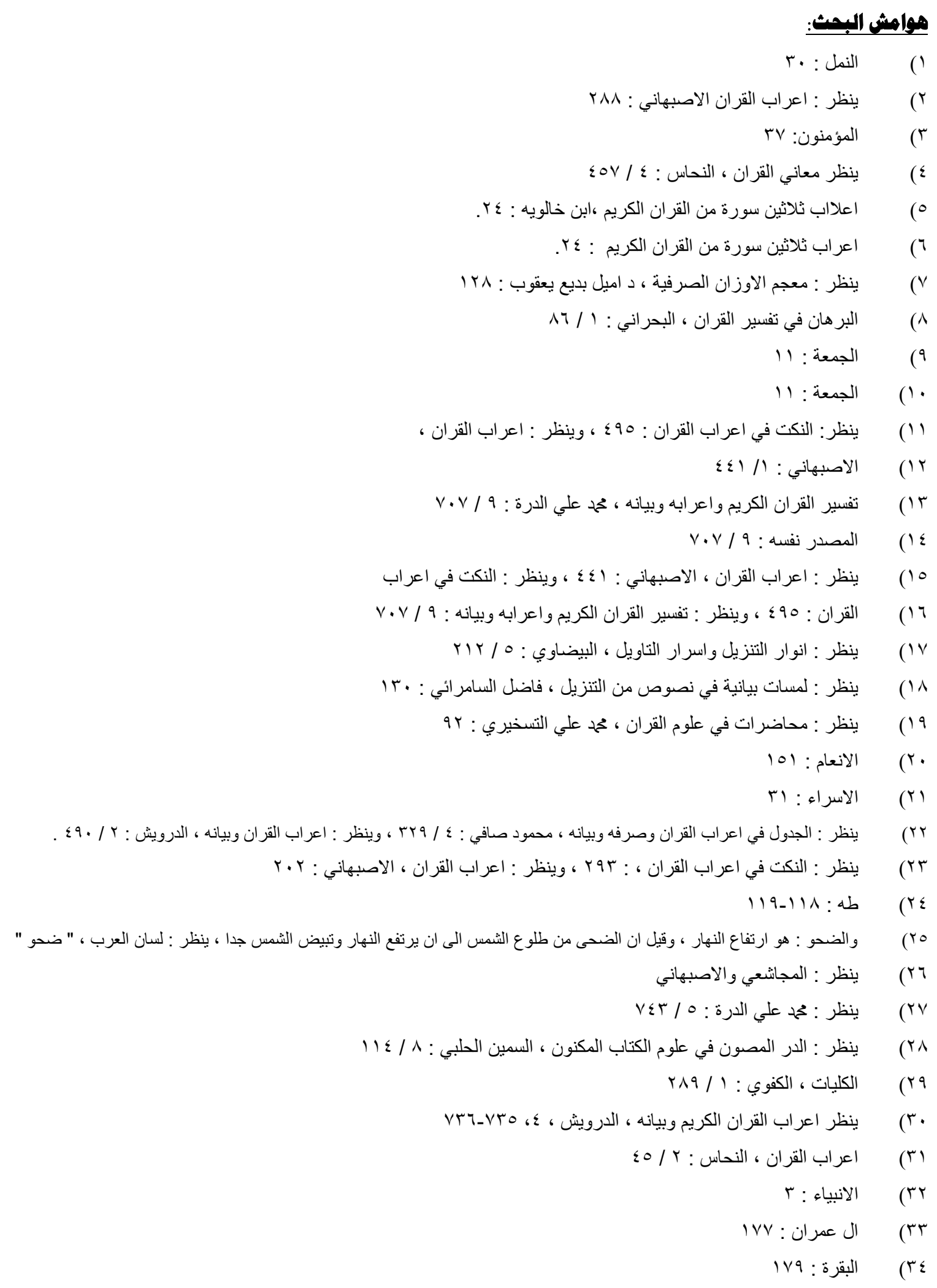




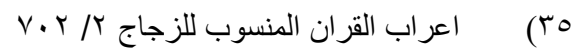

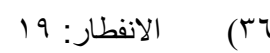

$$
\begin{aligned}
& \text { ( الروم: (rV }
\end{aligned}
$$

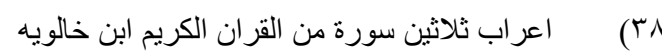

$$
\begin{aligned}
& \text { r: الفاتحة (rq }
\end{aligned}
$$

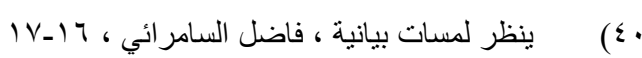

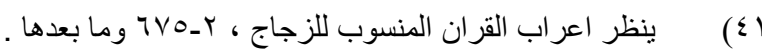

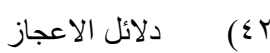

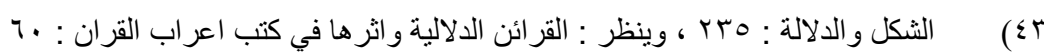

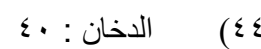

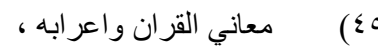

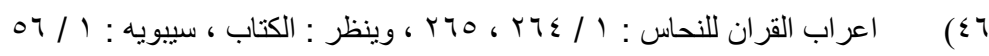

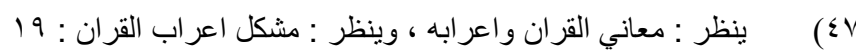

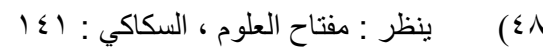

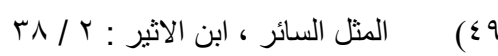

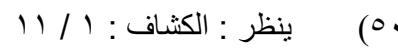

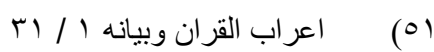

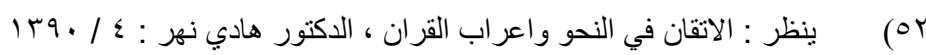

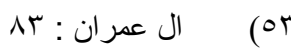

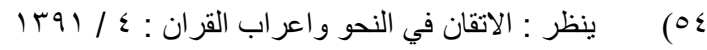

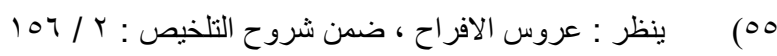

$$
\begin{aligned}
& 0 \text { : الفاتحة : (0) }
\end{aligned}
$$

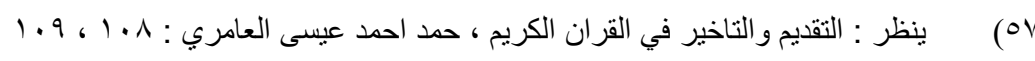

$$
\begin{aligned}
& \text { IVr: البقرة : (ON }
\end{aligned}
$$

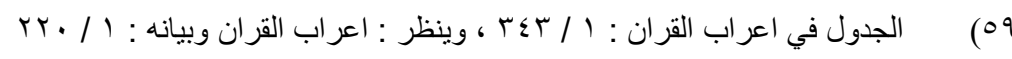

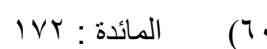

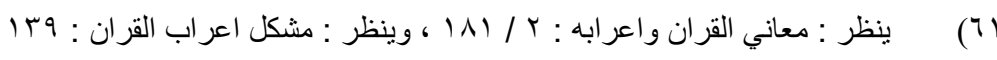

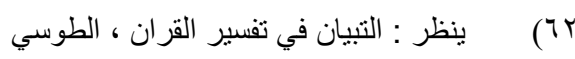

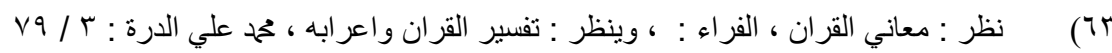

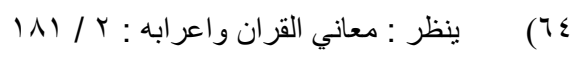

$$
\begin{aligned}
& \text { V : (170 }
\end{aligned}
$$

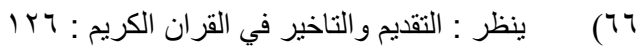

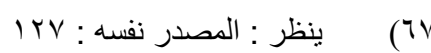

$$
\begin{aligned}
& 0 .: \text { : }
\end{aligned}
$$

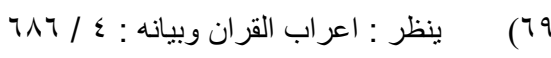

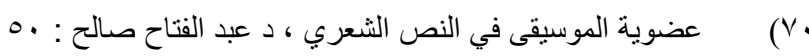

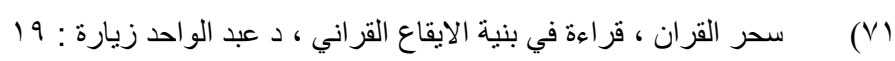

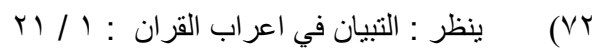

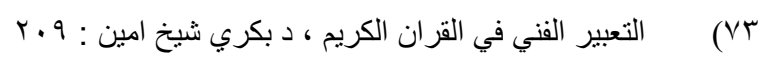

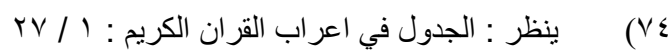


الاتقان في النحو واعراب القران ، د هادي نهر ، عالم الكتب الحديث ، الاردن · ل • ب م .

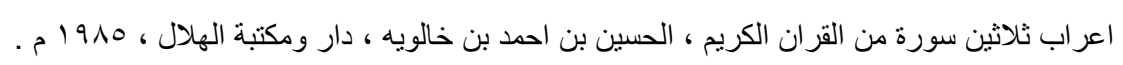

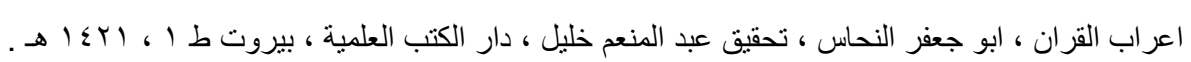

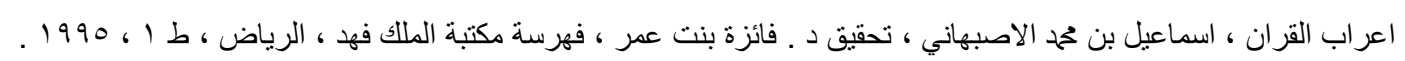

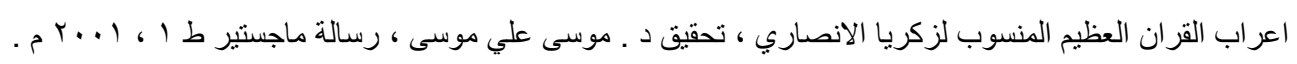

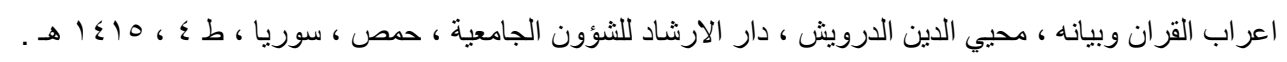

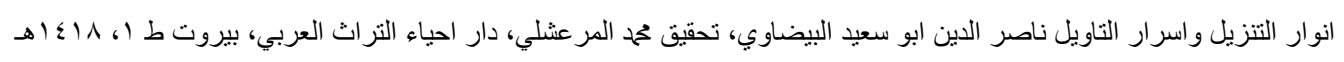
البر هان في تفسير القران ، السيد هاثم البحر اني ، مؤسسة الاعلمي للمطبو عات ، بيروت ـ لبنان ، ط ا ل ، 1999 م م ـ تاويل مشكل القران ، ابن قتيبة الدينوري ، تحقيق ابر اهيم شمس الدين ، دار الكتب العلمية بيروت - لبنان . التبيان في اعر اب القران ، ابو البقاء عبد الله بن الحسين العكبري تحقيق علي محمد البجاوي ، منشورات عيسى البابي الحلبي ، مصر . التبيان في تفسير القران ، ابو جعفر الطوسي ، تحقيق احمد حبيب قصير ، دار احياء التراث العربي .

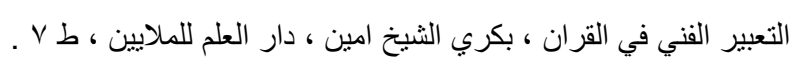

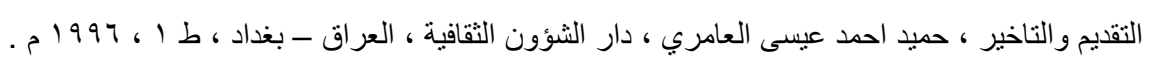

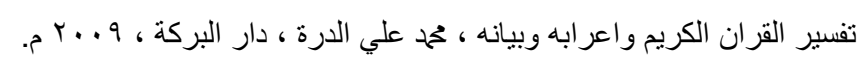

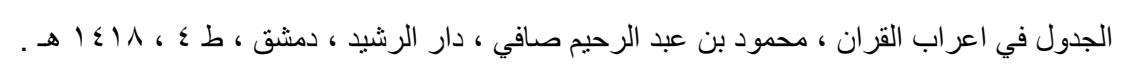

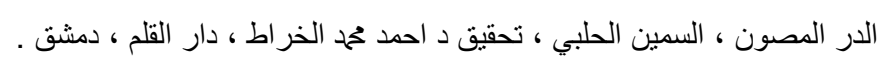

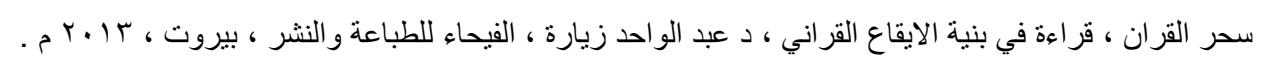

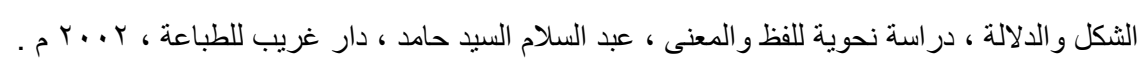

عضوية الموسيقى في النص الثعري ، د عبد الفتاح صالح نافع ، مكتبة المنار ، الاردن ، 1910 م .

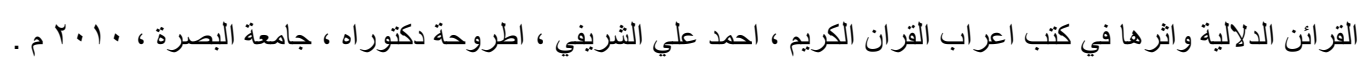

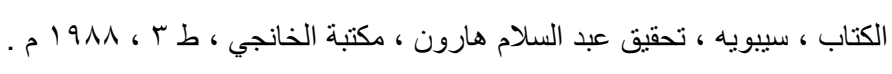

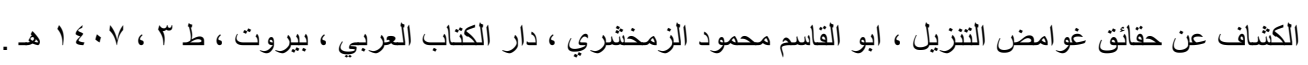

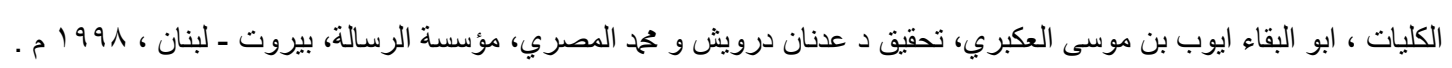

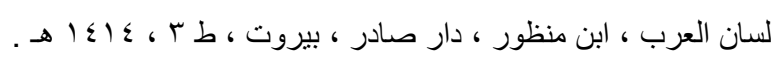
لمسات بيانية في نصوص من التنزيل ، د فاضل صالح السامر ائي ، دار عمار للنشر و التوزيع ، الاردن ، ط ب ، ب . . ب م .

المثل السائر في ادب الكاتب والثاعر ، ابن الاثير ، تحقيق احمد العوفي و بدوي طبانة ، دار نهضة مصر ، القاهرة . مجاز القران ، ابو عبيدة ، تحقيق محمد فؤاد سركين ، مكتبة الخانجي ، القاهرة.

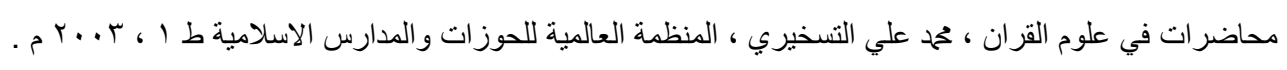

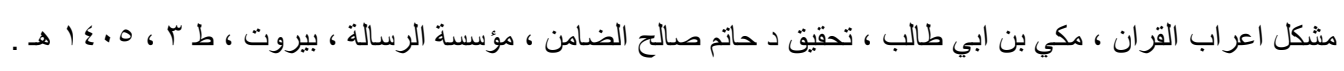

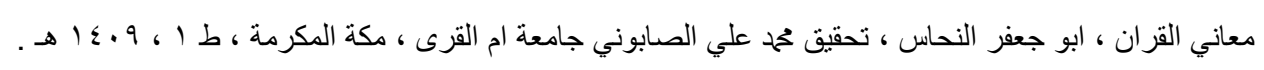

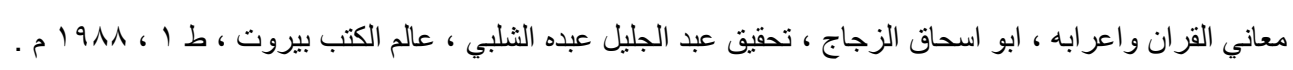

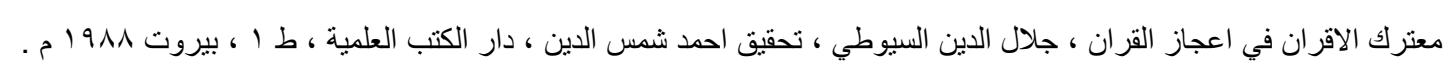

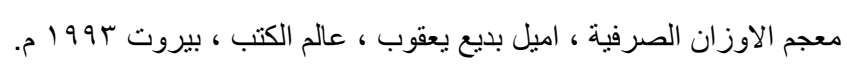

مفتاح العلوم ، يوسف ابي بكر السكاكي، تحقيق نعيم زرزور ، دار الكتب العلمية ، بيروت ، طن ، 19 19 م .

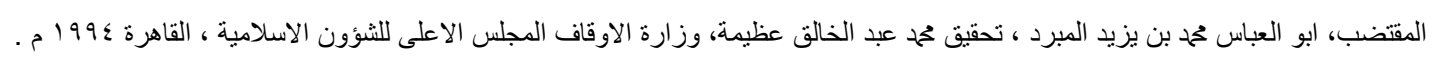

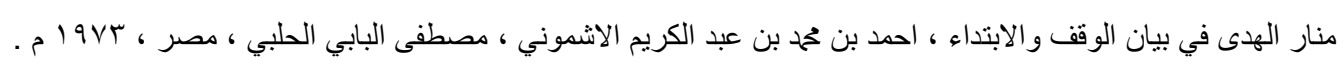

